\title{
Method of discussion and learning styles towards student's critical thinking ability
}

\author{
A. Jauhar Fuad* \\ Institut Agama Islam Tribakti Kediri \\ Jl. KH Wachid Hasyim No.62, Bandar Lor, Kec. Mojoroto, Kota Kediri, Jawa Timur 64114, Indonesia \\ *Corresponding Author. e-mail: info.ajauharfuad@gmail.com
}

\begin{abstract}
Active learning with student centering can improve critical thinking skills. Debates and discussions encourage active learning. Both are oriented toward critical thinking ability, in addition to the learning styles also make an impact on critical thinking ability. This paper aims to answer whether there are (1) differences in students critical thinking ability in the debate class and discussion class, (2) differences in critical thinking ability of students who have divergent learning styles and convergent learning style, and (3) interaction between learning method and learning style to critical thinking ability? This study uses a pseudo experimental design. Subjects in this study are students semester II. An analytical technique using Anova. The results of this study conclude: (1) there is no difference in critical thinking ability between debating class and discussion class, (2) there is the difference of critical thinking ability between convergent learning style and divergent learning style, convergent learning style is better than divergent learning style, and (3) there is an interaction between learning method and learning style to critical thinking ability which means that the influence of learning method on critical thinking ability is influenced by learning style.
\end{abstract}

Keywords: method of discussion, learning style, critical thinking ability

\section{Metode diskusi dan gaya belajar untuk mengasah kemampuan berpikir kritis}

\begin{abstract}
Abstrak
Pembelajaran dengan metode "active learning” yang berpusat pada siswa dapat meningkatkan kemampuan berfikir secara kritis. Debat dan diskusi mampu mendorong siswa untuk belajar secara aktif. Keduanya berorientasi pada kemampuan berfikir kritis. Selain itu, gaya belajar juga memiliki pengaruh terhadap kemampuan berfikir kritis. Penelitian ini bertujuan untuk menjawab apakah ada (1) perbedaan kemampuan berfikir kritis siswa di kelas debat dan kelas diskusi, (2) perbedaan kemampuan berfikir kritis antara siswa dengan gaya belajar divergen dan gaya belajar konvergen, dan (3) interaksi antara metode pembelajaran dan gaya belajar dengan kemampuan berfikir kritis. Penelitian ini menggunakan desain eksperimental semu. Subjek dalam penelitian ini adalah siswa semester II. Teknik analisis menggunakan uji Anova. Hasil penelitian ini yaitu: (1) tidak ada perbedaan kemampuan berfikir kritis antara kelas debat dan kelas diskusi, (2) ada perbedaan kemampuan berfikir kritis antara gaya belajar konvergen dan gaya belajar dimana gaya belajar konvergen ditemukan lebih baik dibandingkan gaya belajar divergen, dan (3) ada interaksi antara metode belajar dan gaya belajar terhadap kemampuan berfikir kritis yang berarti bahwa pengaruh metode belajar terhadap kemampuan berfikir kritis dipengaruhi oleh gaya belajar.
\end{abstract}

Kata Kunci: metode diskusi, gaya belajar, kemampuan berfikir kritis

How to Cite: Fuad, A. J. (2020). Method of discussion and learning styles towards student's critical thinking ability. Jurnal Penelitian Ilmu Pendidikan, 13(1), 1-19. doi:https://doi.org/10.21831/jpipfip.v13i1.23592.

Received 14-02-2019; Received in revised from 22-07-2019; Accepted 29-11-2019

This is an open-access article under the CC-BY-SA license. 
Jurnal Penelitian Ilmu Pendidikan,13 (1), 2020 - 2

A. Jauhar Fuad

\section{INTRODUCTION}

Active learning is useful in increasing understanding, retention, and critical thinking compared to passive learning that results from conventional learning (Hall, 2011). The use of various learning methods can help students develop critical thinking skills (Yildirim \& Ozkahraman, 2011). The ability to think critically can be enhanced by learning that promotes active learning (Walker, 2003; Kennedy, 2007; Snyder \& Snyder, 2008; Mandernach, Forrest, Babutzke \& Manker, 2009; Alexander, 2010). Methods that encourage active student involvement include debate methods and discussion methods (Fuad, 2017).

The results of the study show that critical thinking skills are important for students because many of them fail to utilize their reasoning (Halpern, 1998; Kuhn, 1999). Critical thinking ability is a necessity for success in modern life as a step to address changes that are fast and complex (Ten Dam \& Volman, 2004).

Experts conclude that critical thinking is a very essential ability in life, work, and in all other aspects of life (Simpson \& Courtnery, 2007; Snyder \& Snyder, 2008; Scott, 2008; Kennedy, 2009; Yildirim \& Ozkahraman, 2011; Hall, 2011). Critical thinking as thinking is explicitly based on judgment based on appropriate reasons and standards to find the truth, profit, and value of something (Paul \& Elder, 2001).

The debate in the classroom can effectively facilitate critical thinking. Therefore, a debate is a way to increase critical thinking by looking at arguments, engaging in research, gathering information, conducting analysis, questioning assumptions, and showing interpersonal skills. A debate method is a form of oral controversy that consists of systematic presentations against arguments on topics understood by others. This process involves discussion that is contrary to his views and involved in arguments (Roy \& Macchiette, 2005). Those who have different views clash with each other.

Debate methods have been used successfully in various disciplines including sociology, history, psychology, biotechnology, mathematics, health, dentistry, nursing, marketing, and social sciences (Kennedy, 2007; 2009). Students believe that debate helps them understand topics better, learn new knowledge, and gain an understanding of the process of debate. Also, students believe that debate can improve their critical thinking skills (Scott, 2008).

Debate methods can prepare students to become critical thinkers, become communicators, confident in communicating, improve critical thinking, and solve problems (Hall, 2011). The results of the study show that students gain a better understanding and critical evaluation skills when controversial topics are taught in the form of debate (Omelicheva \& Avdeyeva, 2008).

The discussion method is one method that encourages active student involvement. The discussion method has similarities with the debate method (Braun, 2004). The discussion method is part of learning for several reasons, namely: (1) subjective and controversial topics, (2) complex and new concepts, and (3) effective goals. An example is a discussion that discusses new themes, controversies, and the development of verbal abilities (Slavin, 2006).

The discussion method has a greater effect on students if they are encouraged to engage in controversy rather than just looking for equality of views (Johnson \& Johnson, 1999). The discussion method is superior to the conventional method because, in the discussion method, students are faced with intellectual conflict so that there is an increase in critical thinking skills (Gillman, 2003).

Braun (2004) positions debate and discussion in parallel as a method used in classifying and evaluating a large amount of available information. Students can identify problems and classify information to conclude. Lecturers need to provide active learning activities to help students practice critical thinking.

The results of the study explained that students in the debate class discussed material from various perspectives; whereas in discussions this is not always the case. The debate requires the use of logic and common sense, not just free expression in opinion. Debate participants prepare their abilities so that they know what they are talking about (Goodwin, 2003).

The results of the study concluded that the debate class was pleasant. Students can participate with higher intensity in debate classes than discussion classes (Osborne, 2005). The two studies concluded that the debate method was more favored than the method of discussion.

Another aspect that influences the effectiveness of the use of learning methods is the learning style (Woolfolk, 2008) where learning styles relate to learning models (Joyce, Weil \& Calhoun, 2009). 
Learning styles are approaching the task of learning and managing information in certain ways (Slavin, 2006). Learning style is the ability of students to absorb, organize, and control information. Learning styles are part of the learning conditions that determine the use of learning methods in improving learning outcomes (Degeng, 2012).

This paper focuses more on Kolb's learning style because it has conformity with critical thinking skills. The association of Kolb's learning style has a relationship with critical thinking (Cetin, 2014). Kolb's learning style is divided into four dimensions, namely: divergence, assimilation, convergence, and accommodation (Kolb \& Kolb, 2005). Kolb's learning style can accommodate learning experiences, both those using debate methods and discussion methods. The dimensions of divergent learning styles are compared with convergent learning styles (Kuncoro, 2012; Kade, 2014).

Individuals with divergent learning styles are able to see concrete situations from a variety of perspectives. He is often interpreted as creative thinking (giving lots of ideas) with characteristics: creating ideas, knowing, making alternatives, seeing combinations that are unexpected, open, resilient, self-assertive, and sensitive. While individuals with convergent learning styles are best at finding practical uses of ideas and theories. He is able to solve problems and make decisions effectively. Convergence is often interpreted as critical thinking (choosing the best ideas) with characteristics: good memory, logical thinking, factual knowledge, and accuracy.

Based on the above frame of mind, research problems can be formulated, namely: are there (1) differences in critical thinking skills between students using the debate method and discussion methods, (2) differences in critical thinking skills between students with divergent learning style dimensions and learning styles convergent, and (3) the interaction between learning methods (debate versus discussion) with learning styles (divergent and convergent) towards critical thinking skills.

\section{METHOD}

This study used a quasi-experimental approach with factorial design in carrying out the analysis involving two groups. The experimental group uses the debate method; the control group used the discussion method, as well as divergent and convergent learning styles as moderator variables.

The subjects in this study were students of the Educational Technology Study Program - Faculty of Education and English Language Education Study Program at the Faculty of Letters in the second semester of 2015/2016 academic year at Malang State University. The researcher gave treatment to two parallel classes. This study selected 4 classes, 2 Educational Technology Classes, and 2 English Language Education classes. The reason for choosing two study programs is because each study program has 4 learning groups so that researchers have the flexibility to determine the class to be chosen as the experimental and control classes.

Measurement of learning styles in this study using Kolb's Learning Style Inventory (LSI). This instrument consists of 12 items in the form of multiple-choice statements consisting of four alternative response options. This instrument has been widely used and several reliability tests have been carried out. The instrument of critical thinking skills is based on the learning process in the class that uses the debate method as well as the discussion method. This instrument was developed in the form of rating scales (Fuad, Ardhana, Sulton, \& Dedi, 2016).

Hypothesis testing is carried out by ANOVA statistical analysis techniques. Data analysis was used to determine differences in the use of learning methods (debate versus discussion method) and learning styles (divergent versus convergent) towards students' critical thinking abilities. The criteria for decision making were the difference between the independent variable and the dependent variable based on the error rate of $5 \%$.

\section{RESULTS AND DISCUSSION}

\section{Results}

The researcher conducted a data analysis of critical thinking skills with the help of SPSS software. Each learning group is described in mean size and standard deviation. Table 1, provides a general picture that critical thinking skills between groups of learning methods (debate and discussion) and student learning styles (divergent and convergent). 
Jurnal Penelitian Ilmu Pendidikan,13 (1), 2020 - 4

A. Jauhar Fuad

Table 1. Critical Thinking Ability Learning Style Learning Method

\begin{tabular}{llcc}
\hline \multirow{2}{*}{ Methods } & \multirow{2}{*}{ Learning Style } & \multicolumn{2}{c}{ Critical Thinking } \\
\cline { 3 - 4 } Debate & Mean & $\mathrm{N}$ \\
\hline \multirow{3}{*}{ Discussion } & divergent & 33.4091 & 22 \\
& convergent & 37.3750 & 8 \\
& Total & 34.4667 & 30 \\
\hline \multirow{3}{*}{ Total } & divergent & 36.8421 & 19 \\
& convergent & 36.8889 & 9 \\
& Total & 36.8571 & 28 \\
\hline & divergent & 35.0000 & 41 \\
& convergent & 37.1176 & 17 \\
& Total & 35.6207 & 58 \\
\hline
\end{tabular}

Descriptions of critical thinking skills include: the average critical thinking ability in the learning group that uses the debating method is lower than the learning group that uses the discussion method (mean debate method $=34.4667<$ the mean of the discussion method 36.857). This implies the rejection of the hypothesis which states that the ability to think critically with the debate method is higher than the ability to think critically with the method of discussion. The mean critical thinking ability for students who have divergent learning styles is lower than the students' critical thinking scores who have convergent learning styles (mean divergent learning styles $=35,000<$ mean convergent learning styles $=37.1176)$. This average difference provides an opportunity for acceptance of the hypothesis.

The average critical thinking skills in the group of students who use the debate method and have divergent learning styles are smaller than the average critical thinking skills in the group of students who use the debate method and have a convergent learning style (mean debate-divergent $=33,409$ <average of convergent learning $=37,375$ ). Furthermore, the average critical thinking skills of students who use the discussion method and divergent learning styles are smaller than the average critical thinking skills in students who use the debate method and have a convergent learning style (average discussion-divergent $=36,842$ <average discussion-convergent $=36,889$ ). This indicates the interaction between learning methods with learning styles on critical thinking skills.

Testing the hypothesis by analyzing the data of critical thinking skills as a dependent variable; debate method and discussion method as independent variables; while divergent learning styles and convergent learning styles as moderator variables. In the analysis of hypothesis variants expressed in the formulation of statistical hypotheses, namely the null hypothesis (Ho) and the alternative hypothesis (Ha). The results of the different analyses are presented in Table 2.

Table 2. The Output of the Main Effect

\begin{tabular}{lrrr}
\hline \multicolumn{1}{c}{ Source } & $\begin{array}{c}\text { Type III Sum } \\
\text { of Squares }\end{array}$ & \multicolumn{1}{c}{ F } & Sig. \\
\hline Corrected Model & $175.047^{\mathrm{a}}$ & 6.724 & .001 \\
Intercept & 62491.869 & 7201.239 & .000 \\
Learning methods & 25.985 & 2.994 & .089 \\
Learning style & 48.180 & 5.552 & .022 \\
Interaction learning methods & 45.960 & 5.296 & .025 \\
Learning styles & 74236.000 & & \\
Total & 643.655 & & \\
\hline Corrected Total & & &
\end{tabular}

Table 2 explains the answers to the problems raised. First, critical thinking skills between students who use the debate method, and students who use the discussion method have no difference ( $F=2.994$ with sig. 0.089> 0.05). The learning group that uses the debate method is lower than the learning group that uses the discussion method (average debate method $=34.4667$ <average discussion method 36.857), with a mean difference $=2.3903$.

Second, critical thinking skills between students who have divergent learning styles, and students who have convergent learning styles have differences $(F=5.552$ with sig. $0.012<0.05)$. The scores of 
students' critical thinking skills who have divergent learning styles are lower than convergent learning styles (mean divergent learning styles $=35.00<$ mean convergent learning styles $=37.1176$ ), with a mean difference $=2.1176$.

Third, Table 2 explains that there is an interaction between learning methods (debate and discussion) and learning styles (divergent and convergent) towards critical thinking skills $(\mathrm{F}=5.296$ with sig. $0.025<0.05$ ). Table 1 explains that the average divergent debate $=33,409<$ mean convergent debate $=37,375$ with a mean difference $=3,966$, while the average divergent discussion $=36,842$ <convergent average discussion $=36,889$ with a mean difference $=0,047$. This interaction is seen in the mean convergent debate $=37.375$ with a mean convergent discussion $=36.889$. This means that the discussion method is statistically better than the debate method, seen from the students divergent and convergent learning styles.

\section{Discussion}

Braun (2004) positions debate and discussion in parallel as a method used in business learning to classify and evaluate large amounts of available information. Lecturers need to provide active learning activities to help students practice critical thinking. Students can be taught to identify problems and classify information to make smart decisions. The business curriculum needs to clearly state the critical thinking skills taught and assess skills improvement. This is no easy task, but a fast-paced environment in the business world requires executives and workers to be able to handle large amounts of information and make wise decisions quickly.

Braun's findings (2004) if related to the results of this study, which states the critical thinking skills of students who use the debate and discussion methods are the same. This means that the debate method does not multiply more than the method of discussion. The results of this study indicate that the discussion method is better than the debate method. In the results of other studies, the students suggested that debate helped them practice presentation skills and teamwork. All students enjoy participating in the debate.

Debate methods can measure student achievement and diagnose learning problems. They learn more about their perspectives and attitudes towards the material being studied. But unfortunately, not all debates are very good tools in learning. The debates conducted in the class did not get the benefits of learning evenly for each student. Some students fail to gain more understanding of controversial issues or practice critical thinking skills, and others express fears and anxieties over academic debates (Omelicheva, 2007).

Gillman's research results actually reinforce the rejection of the hypothesis. It was stated that the discussion method was superior to the conventional method because in the discussion method students were faced with intellectual conflict so that there was an increase in critical thinking skills (Gillman, 2003). The discussion method is perceived to speed up gaining knowledge, improve critical thinking skills, facilitate understanding facts and opinions, and help students think critically. The results of the above research can confirm that not only the debate method can improve students' critical thinking abilities but the discussion method also has the same ability (Fuad, 2015).

The results of this study indicate that students with convergent learning styles are more favored in achieving critical thinking skills than students who have divergent learning styles. Thus, this study resulted in students who had a convergent learning style more favored in critical thinking skills than students who had divergent learning styles.

Learning styles can be interpreted as characteristics of cognitive, affective, and psychological behavior of a student about how he understands something, interacts and responds to his learning environment, which is unique and relatively stable (Kolb and Kolb, 2005). Critical thinking consists of mental tendencies and the ability of individuals to draw conclusions about the information provided, identify issues and assumptions in arguments, and evaluate their evidence.

Both the capacity of learning and critical thinking styles involves the management of individual habits and the transformation of information provided; the first is the action and the second is the disposition and skills of the action (Andreou, Papastavrou, \& Merkouris, 2014). Furthermore, there is a positive relationship between learning styles and critical thinking skills if total learning styles are considered as the focus of research (Karamloo, 2014). The results of this study have similarities with previous studies where students who have convergent learning styles have the ability to organize and receive information received from the text (Fuad, 2016). 
Furthermore, it was stated that students can learn from their own work, use their own strategies to take notes, and underline the parts that are considered important. They can also read parts that are less clear or missing. They are also actively involved in discussions with the help of questions given or with instructions given. Students who have convergent learning styles have the opportunity to use narratives, create their own learning strategies, and ask questions about points that are not understood and together with the lecturers use their own communication styles (Y1lmaz-Soylu \& Akkoyunlu, 2002). The findings of this study are the same as those of Kuncoro (2012), namely that different types of learning styles have different influences on problem-solving. Convergent learning style groups are superior to divergent learning style groups in problem-solving.

Regarding the opinion of Kuncoro (2012), Kade (2014) concluded that students who have convergent learning styles tend to have a better understanding of concepts compared to students who have divergent learning styles in high school students. Students who have different learning styles make it possible to have different thinking skills. Convergent learning styles are more favored than divergent learning styles in developing critical thinking skills.

Convergent learning styles are in abstract conceptual positions and are active in conducting experiments. An individual with an abstract conceptual orientation focuses on using logic, ideas, and concepts. This orientation emphasizes scientific and systemic thinking. While individuals who are oriented towards active experiments focus on changing situations (Fuad, 2016). This person is able to take risks to achieve their goals. The emphasis is on doing and seeing results (Kolb and Kolb, 2005).

The positive relationship between convergent learning styles and critical thinking is also explained by Gyeong \& Myung's research. It was stated that students who learn by thinking of the possibility to combine critical thinking capacity and learning outcomes to the fullest, he was able to anticipate situations to change new information (Gyeong \& Myung, 2008). Convergent learning styles as preferences for solving problems that have definite answers (Ross \& Lukow, 2004). Students who have convergent learning styles achieve the highest score when they use investigative-based methods (Tulbure, 2011).

Hair, Black, Babin, Anderson \& Tatham (2006) suggest that interactions can occur if the independent variables do not carry causation separately or individually. Franzoni \& Assar (2009) explain learning styles combined with the selection of appropriate learning methods that have an impact on learning processes and outcomes.

Novin, Arjomand, and Jourdan (2003) emphasize that lecturers are aware of the importance of exposing students to use various learning styles, in addition to the learning styles they like. By understanding student learning styles, lecturers can maximize their students' potentials and ignore their weaknesses. The results of this study underscore the importance of distinguishing learning methods that address all learning styles. Jones, Reichard, \& Hokhtari (2003) concluded that learning styles play an important role in the learning process. Franzoni \& Assar (2009) explain the possibility that both learning styles groups can do the same thing well with one of the learning methods.

Some people learn by seeing; some by thinking; some by saying and so on. The ways in which an individual typically acquires, retains, and retrieves information are called individual learning styles (Felder \& Henriques, 1995). The results of other studies about the relationship between learning styles, learning environments, and suitability of student performance in different types of learning environments were carried out by McCann (2006).

The results of the study explained that optimal learning requires students to receive learning tailored to their learning styles. This study reveals a specific type of interaction between learning styles and learning methods where students with one learning style achieve the best learning goals when given different learning methods.

Good learning methods can accommodate different learning styles. In other words, learning methods that prove most effective for students with a learning style are not the most effective method for students with different learning styles. The results of the study explain that there is almost no evidence for the interaction pattern mentioned above, which is considered to be a prerequisite for validating learning applications with learning styles. Therefore, there is no sufficient evidence base to justify the incorporation of learning-style assessments in educational practice (Pashler, McDaniel, Rohrer \& Bjork, 2009).

Baldwin \& Sabry (2003) emphasize the learning style that needs to be developed so that students can show certain skills of each learning style they have. Learning methods can not only help students to 
be able to respond more effectively to different learning situations but can also act as the formation of more autonomous students. Franzoni, \& Assar, (2009) show that students tend to learn in different ways, choosing to use learning methods that they prefer.

The study of interactions that arise between methods and learning styles is the basis for understanding the results of testing the third hypothesis. This implies that the influence of learning methods on critical thinking skills is influenced by learning styles. The above study is the basis for building the idea that the interaction of learning methods and learning styles towards critical thinking skills appears presumably because of the strong influence of each variable, namely the independent variables (debate method and discussion method) affect moderator variables (divergent learning styles). and convergent learning styles) on variables bound to critical thinking skills.

The discussion method has a tendency to be presented in the form of brainstorming and directed to find conclusions and decisions at the end of the conversation. While the debate method has the tendency to strengthen the argumentation on a view, each party reinforces each other's views, so that the audience can see which argument is better. Talks do not produce conclusions or decisions.

Students who have different learning styles may have different ways of learning. Researchers argue that there is a correlation between learning styles and learning methods where convergent learning styles have stronger interactions with the debate method while divergent learning styles have stronger interactions with the discussion method. Thus, convergent learning styles interact with the debate method on critical thinking skills

\section{CONCLUSION}

Based on the results of data analysis, several conclusions can be made. First, there is no difference in students' critical thinking skills, both those using the debate method and those using the discussion method. The critical thinking ability of students who use the debate method is no higher than the method of discussion. Second, there are differences in students' critical thinking skills between those who have convergent learning styles and those with divergent learning styles. Students' critical thinking skills in a convergent learning style are higher than students who are divergent learning styles. Third, there is an interaction between learning methods and learning styles towards critical thinking skills. This means that the contribution of learning methods to critical thinking skills is accommodated by learning styles. The discussion method is suitable for divergent learning power and convergent learning styles.

Based on the research conclusions, the following series of activities are suggested to be considered for follow-up, both by researchers and lecturers. First, the sociocultural conditions of Indonesian students differ from those of students, both in America and Europe who are accustomed to expressing opinions, so it is necessary to develop active learning that can promote students' critical thinking skills more effectively. Second, there is a need to strengthen the mechanism for implementing learning, both using debate methods and discussion methods, by conducting longer simulations so that students do not experience difficulties in carrying out learning. Third, lecturers need to pay attention to active learning methods, both discussion methods, and debate methods. Both learning methods encourage students to learn to cooperate, learn to speak in public, learn to argue and train them to deal with different opinions and respect the opinions of others. Fourth, lecturers need to pay attention to the learning styles that students have because learning that is done in accordance with the learning style will work well. They can participate in the learning process so that learning gains can be achieved well.

\section{BIBLIOGRAPHY}

Alexander, M. E. (2010). Using the four-questions technique to enhance critical thinking in online discussions. Merlot Journal of Online Learning and Teaching, 6(2), 409-415.

Andreou, C., Papastavrou, E. \& Merkouris, A. (2014). Learning styles and critical thinking relationship in baccalaureate nursing education: A systematic review. Nurse Education Today, 34(3), 362371.

Baldwin, L. \& Sabry, K., (2003). Learning styles for interactive learning systems. Innovations in Education and Teaching International, 40(4), 325-340.

Braun, N. M. (2004). Critical thinking in the business curriculum. Journal of Education for Business, 79(4), 232-236. 
Cetin, M. C. (2014). Evaluation of the correlation between learning styles and critical thinking dispositions of the students of school of physical education and sports. Academic Journals, 18(9), 680-690.

Degeng, I. N. S. (2012). Ilmu pembelajaran, klasifikasi variabel untuk pengembangan teori dan penelitian. Bandung: Aras Media.

Felder, R. M. \& Henriques, E. R. (1995). Learning and teaching styles in college science education. Journal of College Science Teaching, 23, 286-290.

Franzoni, A. L. \& Assar, S. (2009). Student learning styles adaptation method based on teaching strategies and electronic media. Educational Technology \& Society, 12(4), 15-29.

Fuad, A. J., Ardhana, I. W., Sulton, S, \& Kuswandi, D. (2016). Construction measurement critical thinking. ASEAN Conference 2nd Psychology \& Humanity: Optimizing Human Strenght for Productivity and Well Being. Malang, 19-20 February 2016.

Fuad, A Jauhar. (2015). Gaya Belajar Kolb dan Percepatan Belajar. In Seminar Psikologi \& Kemanusiaan, 6. Malang: Pychology Forum UMM.

Fuad, A. J. (2016). Meta analisis: Deferensiasi gaya belajar dengan metode pembelajaran. Journal AnNafs: Kajian Penelitian Psikologi, 1(2): 151-65. https://doi.org/10.33367/psi.v1i2.284.

Fuad, A. J. (2017). Kemampuan berpikir kritis warga negara dan kekuatan metode debat. JINOTEP (Jurnal Inovasi dan Teknologi Pembelajaran) Kajian dan Riset dalam Teknologi Pembelajaran, l(1): 58-67.

Gillman, J. H. (2003). A discussion format for improving critical thinking on issues affecting nursery management. NACTA Journal, 1(4), 40-42.

Goodwin, J. (2003). Students' perspectives on debate exercises in content area classes. Communication Education, 52(2), 157-163.

Gyeong, J. A. \& Myung, S. Y. 2008. Critical thinking and learning styles at the baccalaureate nursing program in Korea. Contemporary Nurse, 29(1), 100-109.

Hair, Jr., J. F., Black, W. C., Babin, B. J., Anderson, R. E. \& Tatham, R. L. (2006). Multivariate data analysis (6th ed.). Upper Saddle River, NJ: Pearson Prentice Hall.

Hall, D. (2011). Debate: innovative teaching to enhance critical thinking and communication skills in healthcare professionals. The Internet Journal of Allied Health Sciences and Practice, 9(3), 1-8.

Halpern, D. F. (1998). Teaching critical thinking for transfer across domains. American Psychologist, 53(9), 449-455.

Johnson, D. W. \& Johnson, R. T. (1999). Learning together and alone: Cooperative, competitive, and individualistic learning. Boston: Allyn \& Bacon.

Jones, C., Reichard, C. \& Hokhtari, K. (2003). Are students' learning styles discipline-specific? Community College Journal of Research and Practice, 27, 363-375.

Joyce, B., Weil, M. \& Calhoun, E. (2009.) Models of teaching (8th ed.). Boston: Pearson.

Kade, A. (2014). Pengaruh pembelajaran kooperatif tipe jigsaw dan gaya belajar terhadap pemahaman konsep fisika siswa SMA Negeri di Palu. Disertasi. Malang: PPS Universitas Negeri Malang tidak diterbitkan.

Karamloo, S. (2014). The relationship between critical thinking ability and learning styles of Iranian male and female EFL learners. Journal of Academic and Applied Studies (Special Issue on Applied Sciences), 4(2), 1-12.

Kennedy, R. R., (2007). In-class debates: fertile ground for active learning and the cultivation of critical thinking and oral communication skills. International Journal of Teaching and Learning in Higher Education, 19(2), 183-190.

Kennedy, R. R., (2009). The power of in-class debates. Active Learning In Higher Education, 10(3), 112.

Kolb, A.Y, Kolb, D.A. (2005). Learning styles and learning spaces: Enhancing experiential learning in higher education. The Academy of Management Learning and Education, 4(2), 193-212.

Kuhn, D. (1999). A developmental model of critical thinking. Educational Researcher, 28(1), 16-26.

Kuncoro, T. (2012). Pengaruh strategi pembelajaran problem solving dan gaya belajar kolb terhadap hasil belajar bidang matematika rekayasa mahasiswa jurusan teknik sipil. Disertasi. Malang: PPS Universitas Negeri Malang tidak diterbitkan. 
Mandernach, B. J., Forrest, K. D., Babutzke, J. L. \& Manker, L. R. (2009). The role of instructor interactivity in promoting critical thinking in online and face-to-face classrooms. Merlot Journal of Online Learning and Teaching, 5(1), 49-62.

McCann, B. M. (2006). The relationship between learning styles, learning environments, and student success. Journal of Agricultural Education, 47(3), 14-23.

Novin, A. M., Arjomand, L. H. \& Jourdan, L. (2003). An Investigation into the preferred learning styles of accounting, management, marketing, and general business majors. Teaching \& Learning, 18(1), 24-31.

Omelicheva, M. Y. \& Avdeyeva, O. (2008). Teaching with lecture or debate? Testing the effectiveness of traditional versus active learning methods of instruction. PS: Political Science and Politics, (July): 03-07.

Omelicheva, M. Y. (2007). Resolved: academic debate should be a part of political science curricula. Journal of Political Science Education, 3, 161-177.

Osborne, A. (2005). Debate and student development in the history classroom. New Directions for Teaching \& Learning, 103, 39-50.

Pashler, H., McDaniel, M., Rohrer, D. \& Bjork, R. (2009). Learning styles concepts and evidence. Association for Psychological Science, 9(3): 105-119.

Paul, R. \& Elder, L. (2001). Critical thinking: tools for taking charge of your learning and your life. Upper Saddle River, N.J.: Prentice-Hall.

Ross, C. M. \& Lukow, J. E. (2004). Are learning styles a good predictor for integrating instructional technology into a curriculum? Journal of Scholarship of Teaching and Learning, 4(1), 41-51.

Roy, A. \& Macchiette, B. (2005). Debating the issues: a tool for augmenting critical thinking skills of marketing students. Journal of Marketing Education, 27(3), 264-276.

Scott, S. (2008). Perceptions of students' learning critical thinking through debate in a technology classroom: a case study. The Journal of Technology Studies, 34(1), 39-44.

Simpson, E. \& Courtnery, M. (2007). The development of a critical thinking conceptual model to enhance critical thinking skills in middle-eastern nurses: a middle-eastern experience. Australian Journal of Advanced Nursing, 25(1), 56-63.

Slavin, R. E. (2006). Educational psychology: Theory and practice (8th ed.). Boston, MA: Pearson.

Snyder, L. G. \& Snyder, M. J. (2008). Teaching critical thinking and problem-solving skills. The Delta Pi Epsilon Journal, 50(2), 90-99.

Ten Dam, G. \& Volman, M. (2004). Critical thinking as a citizenship competence: teaching strategies. Learning and Instruction, 14(4), 359-379.

Tulbure, C. (2011). Do different styles require differentiated teaching strategies? Procedia Social and Behavioral Sciences, 11, 155-159.

Walker, S. E. (2003). Active learning strategies to promote critical thinking. Journal of Athletic Training, 38(3), 263-267.

Woolfolk, A. (2008). Educational psychology: Active learning. New Jersey: Pearson Education.

Yildirim, O. B. \& Ozkahraman, S. (2011). Critical thinking in nursing process and education. International Journal of Humanities and Social Science, 13(1), 257-262.

Y1lmaz-Soylu, \& Akkoyunlu, B. (2002). The effect of learning styles on achievement in different learning environments. The Turkish Online Journal of Educational Technology - TOJET, 8(4), 43-50. 